\title{
Penerapan Metode Diskusi-Presentasi Dipadu Analisis Kritis Artikel melalui Lesson Study untuk Meningkatkan Pemahaman Konsep, Kemampuan Berpikir Kritis, dan Komunikasi
}

\author{
Zuni Mitasari, Nugroho Aji Prasetiyo
}

Progam Studi Pendidikan Biologi, FIP, Universitas Tribhuwana Tunggadewi

J1. Telaga Warna, Tlogomas, Malang, 65 I44 Indonesia

\begin{abstract}
ABSTRAK
Tujuan penelitian ini adalah untuk mengetahui keberhasilan penerapan metode diskusi-presentasi dipadu dengan analisis kritis artikel dalam meningkatkan pemahaman konsep, kemampuan berpikir kritis, dan komunikasi mahasiswa pada matakuliah Biologi Umum. Jenis penelitian ini adalah Penelitian Tindakan Kelas (PTK) melalui Lesson Study (LS) dengan pendekatan deskriptif kualitatif. Penelitian ini terdiri atas tiga siklus, setiap siklus menggunakan langkah-langkah PTK yang terdiri atas empat tahap yaitu (I) perencanaan, (2) pelaksanaan, (3) observasi, dan (4) refleksi dan terintegrasi dengan tiga tahapan LS, yaitu (I) plan, (2) do, dan (3) see. Berdasarkan hasil analisis data, rata-rata pemahaman konsep mahasiswa pada tiga materi yang diajarkan yaitu $82 \%$. Rata-rata nilai kelas hasil kemampuan berpikir kritis pada siklus I, II, dan III secara berurutan, yaitu 76, 87, dan 90. Peningkatan kemampuan berpikir kritis dari siklus I ke II dan siklus II ke III sebesar I5\% dan 3,4\%. Rata-rata nilai kemampuan komunikasi pada siklus I, II, dan III secara berurutan, yaitu 52, 63, dan 63. Peningkatan kemampuan komunikasi dari siklus I ke II dan dari siklus II ke III secara berurutan sebesar 21\% dan 0\%. Berdasarkan hasil penelitian ini dapat disimpulkan bahwa penerapan metode diskusi-presentasi dipadu dengan analisis kritis artikel dapat meningkatkan pemahaman konsep, kemampuan berpikir kritis, dan komunikasi mahasiswa.
\end{abstract}

Kata kunci: Diskusi-Presentasi, Analisis Kritis, Pemahaman Konsep, Berpikir Kritis, Komunikasi

\section{Pendahuluan}

Dosen sebagai pendidik profesional dengan tugas utama mendidik, mengajar, membimbing, mengarahkan, melatih, menilai, dan mengevaluasi peserta didik membutuhkan peningkatan profesional secara terus menerus. Melalui Penelitian Tindakan Kelas (PTK), seorang pendidik memperoleh pemahaman tentang apa yang harus dilakukan, merefleksi diri untuk memahami dan menghayati nilai pendidikan dan pembelajarannya sendiri, dapat bekerja secara kontekstual, dan mengerti sejarah tentang pendidikan (Kemmis dan Mc Taggart dalam Aswandi, 2006).

Penelitian tindakan kelas dapat dijadikan sarana bagi pendidik dalam meningkatkan kualitas pembelajaran secara efektif (Sukanti, 2008). PTK memiliki potensi yang sangat besar untuk meningkatkan pembelajaran apabila diimplementasikan dengan baik dan benar. Pendidik dapat meningkatkan pembelajaran dengan cara melakukan kolaborasi dengan pendidik lain untuk merancang, mengamati, dan melakukan refleksi terhadap pembelajaran yang dilakukan (Syamsuri, 2008).

Sehubungan dengan strategi peningka-tan kualitas pembelajaran tersebut, pendidik juga dapat meningkatkan pembelajaran melalui kegiatan lesson study. Mulyana (2006) memberikan rumusan tentang lesson study sebagai salah satu model pembinaan profesi pendidik melalui pengkajian pembelajaran secara kolaboratif dan berkelanjutan berlandaskan pada prinsip-prinsip kolegalitas dan mutual learning untuk membangun komunitas belajar.

Berdasarkan hasil observasi pada kelas penelitian maka ada tiga masalah utama yang teridentifikasi, yaitu (I) kurangnya pemahaman konsep mahasiswa pada materi yang dipelajari, (2) kurangnya kemampuan mahasiswa dalam menganalisis kritis materi bahan presentasi sehingga isi power point yang disajikan kelompok penyaji saat kegiatan presentasi bukan poinpoin penting materi yang seharusnya disampaikan sehingga terkesan hanya copy-paste dari artikel, dan (3) 
kurangnya kemampuan mahasiswa dalam komunikasi, hal ini terlihat saat kegiatan presentasi, mahasiswa penyaji hanya membaca materi pada power point sehingga mahasiswa tampak kurang memahami materi yang disampaikan.

Diskusi adalah metode pembelajaran yang menghadapkan siswa pada suatu permasalahan (Majid, 2013) sedangkan presentasi adalah metode pengungkapan ide, gagasan, perasaan di depan umum oleh satu atau lebih presenter dengan menyertakan naskah makalah atau tidak (Somantri, 2005). Selanjutnya analisis kritis artikel merupakan suatu metode mengkaji dan mencermati artikel untuk mengambil isi artikel yang relevan sesuai dengan tata cara penulisan artikel (Dewan Riset Nasional, 2013).

Pemahaman konsep adalah pemahaman akan suatu materi yang tidak hanya pada tingkat mengingat konsep saja tetapi harus mampu mengungkapkan kembali dalam bentuk lain tanpa mengubah makna yang terkandung pada konsep tersebut (Purwanto, 2008). Indikator pemahaman konsep mencakup enam domain kognitif, mengacu pada Taksonomi Bloom (Anderson dan Krathwol, 200I) yang telah direvisi, yaitu mengingat (CI), memahami (C2), menerapkan (C3), menganalisis (C4), mengevaluasi (C5), dan mencipta (C6).

Berpikir kritis adalah berpikir logis dan reflektif yang difokuskan pada pengambilan keputusan (Ennis, 20II). Menurut Kusumawati (20I4), keterampilan berpikir kritis memungkinkan mahasiswa memeriksa isu, melihat fenomena dari sudut pandang yang berbeda, dan memiliki fleksibilitas untuk merestrukturisasi pemikiran yang menjadi dasar dalam melakukan segala sesuatu. Agar mampu berpikir secara kritis, seseorang harus membaca dengan kritis (Hassoubah, 2004). Interaksi dalam diskusi kelompok memiliki peran yang penting dalam merangsang kemampuan berpikir kritis (Filsaime, 2008).

Kemampuan komunikasi merupakan bagian dari kemampuan sosial yang diperlukan untuk bekal hidup dalam bermasyarakat. Terkait hal tersebut maka sekolah bisa dijadikan miniatur masyarakat untuk mendidik mahasiswa dalam melatih kemampuan komunikasi dengan orang lain. Beberapa unsur komunikasi, yaitu sumber, komunikator, pesan, saluran, penerima pesan dan hasil (Ulya, 20II).

Berdasarkan hal tersebut, maka tujuan penelitian ini adalah (I) untuk mengetahui peningkatan pemahaman konsep melalui metode diskusi-presentasi dipadu dengan analisis kritis artikel (2) untuk mengetahui peningkatan kemampuan berpikir kritis melalui metode diskusipresentasi dipadu dengan analisis kritis artikel (3) untuk mengetahui peningkatan kemampuan komunikasi melalui metode diskusi-presentasi dipadu dengan analisis kritis artikel (4) untuk mengetahui penerapan metode diskusi-presentasi yang dipadu dengan analisis kritis artikel sehingga dapat meningkatkan pemahaman konsep, kemampuan berpikir kritis, dan komunikasi.

\section{Metode Penelitian}

Penelitian ini termasuk dalam Penelitian Tindakan Kelas (PTK) atau Classroom Action Research (CAR) melalui lesson study karena masalah yang akan diteliti adalah masalah yang terjadi dalam kegiatan pembelajaran. Pendekatan dalam penelitian ini adalah pendekatan deskriptif kualitatif karena data yang dikumpulkan berupa data deskriptif dan naratif (Moleong 20I I).

Obyek penelitian adalah mahasiswa semester gasal tahun ajaran 20I4/20I5 Kelas A/Off A SI Pendidikan Kimia, Jurusan Kimia, Universitas Negeri Malang. Mahasiswa berjumlah 26 orang yang terdiri atas 5 orang laki-laki dan 2I orang perempuan. Tempat dilakukannya penelitian ini adalah ruang 108 Gedung Biologi Universitas Negeri Malang. Waktu penelitian yaitu bulan Oktober sampai November 2014.

Langkah-langkah PTK menggunakan model PTK oleh Kemmis \& Mc Taggart Penelitian tindakan kelas terdiri atas empat tahap, yaitu (I) perencanaan, (2) pelaksanaan, (3) observasi, dan (4) refleksi. Penelitian lesson study terdiri atas tiga tahap, yaitu (I) perencanaan (plan), (2) pelaksanaan (do), dan refleksi (see). Penelitian ini merupakan penelitian tindakan kelas melalui lesson study sehingga perencanaan untuk tahap penelitiannya, yaitu setiap kali siklus PTK terdiri atas 4 tahapan PTK dan pada tahap kedua (pelaksanaan) maka terdiri atas 3 tahapan lesson study, yaitu plan, do, dan see.

Jenis data yang diperoleh dari penelitian ini berupa data kualitatif dan kuantitatif. Data kuantitatif berupa persentase keterlaksanaan pembelajaran, nilai pemahaman konsep, nilai kemampuan berpikir kritis, dan nilai kemampuan komunikasi melalui kegiatan presentasi. Data kualitatifnya berupa hasil observasi lesson study dan respon mahasiswa terhadap metode pembelajaran. Instrumen yang digunakan dalam penelitian ini, yaitu lembar keterlaksanaan pembelajaran, rubrik penilaian pemahaman konsep, kemampuan berpikir kritis, dan kemampuan komunikasi, lembar observasi keterlaksanaan lesson study, dan lembar respon mahasiswa terhadap kegiatan pembelajaran.

\section{Hasil dan Pembahasan}

Lesson study dilakukan berulang kali dalam waktu yang lama karena setiap proses pembelajaran tidak selalu sama dan tidak ada proses pembelajaran yang sempurna sehingga siklusnya akan terus berulang (Syamsuri, 2008). Langkah pertama dalam Penelitian Tindakan Kelas (PTK) melalui Lesson Study (LS) yaitu observasi. Observasi ini bertujuan untuk menemukan permasalahan utama yang dihadapi oleh kelas yang akan menjadi obyek penelitian. Observasi dilakukan sebanyak dua kali.

Berdasarkan permasalahan yang ditemukan saat observasi maka dicarikan solusi atas permasalahan tersebut, ada dua macam metode belajar yang dipih 
dalam penelitian yaitu diskusi-presentasi dan analisis kritis artikel. Metode diskusi-presentasi adalah metode pembelajaran yang bertujuan untuk mengungkapkan ide, gagasan, atau masalah di depan umum. Kemudian gagasan tersebut dicari pemecahannya secara bersamasama oleh mahasiswa-mahasiswa dalam kelas dengan tujuan untuk menjawab pertanyaan, menambah dan memahami pengetahuan, serta untuk membuat suatu keputusan. Sedangkan analisis kritis artikel adalah suatu metode mengkaji dan mencermati artikel untuk mengambil isi artikel yang relevan sesuai dengan tata cara penulisan artikel.

Langkah pembelajaran Biologi Umum dengan metode diskusi-presentasi dipadu dengan analisis kritis artikel yaitu mahasiswa diberikan tugas untuk mencari artikel ilmiah kemudian menganalisisnya sesuai rubrik analisis kritis artikel. Kegiatan awal pembelajaran yang dilakukan yaitu mahasiswa presentasi materi sesuai topik pada setiap siklus kemudian melakukan diskusi kelas, setelah itu mahasiswa mempresentasikan hasil kajian analisis kritis artikelnya.

Materi yang diajarkan dalam penelitian ini, yaitu (I) siklus pertama tentang keanekaragaman organisme sistem lima kingdom (monera, protista, fungi, plantae, dan animalia), (2) siklus kedua tentang struktur dan fungsi jaringan, organ tumbuhan, dan proses metabolisme tumbuhan, serta (3) siklus ketiga tentang proses pertumbuhan dan perkembangan, proses reproduksi tumbuhan, dan proses metabolisme tumbuhan. Persentase keterlaksanaan kegiatan pembelajaran siklus pertama, kedua, dan ketiga berturutturut yaitu 93\%, 90\%, dan $100 \%$.

Berdasarkan hasil analisis pemahaman konsep, ratarata nilai kelas yaitu 82 sehingga dapat disimpulkan persentase pemahaman konsep mahasiswa $(\mathrm{P})$ pada tiga materi yang diajarkan yaitu $82 \%$. Persentase $82 \%$ tersebut berada pada rentangan $75 \%<\mathrm{P}<100 \%$ sehingga tergolong ke dalam nilai pemahaman konsep tinggi. Pemahaman adalah rekonstruksi makna dan hubungan-hubungan bukan hanya sekedar asimilasi dari pengetahuan yang sudah dimiliki sebelumnya. Pemberian pengalaman belajar di dalam kelas secara efektif berperan penting dalam membantu terbentuknya pemahaman konsep siswa (Setiawan, 2013).

Pembelajaran biologi tidak hanya belajar tentang makhluk hidup saja tetapi juga mengajarkan berbagai macam keterampilan, diantaranya keterampilan berpikir kritis dan keterampilan dalam penyelidikan sesuai dengan prosedur ilmiah. Jika keterampilan berpikir kritis dilatihkan secara terus menerus maka akan menjadi kebiasaan dan terinternalisasi dalam watak seseorang untuk cenderung berpikir kritis dalam menghadapi segala sesuatu (Marzano, et al, 1998).

Kemampuan-kemampuan kognitif yang berbasis pemahaman melibatkan kemampuan berpikir tingkat tinggi, seperti pemecahan masalah, berpikir kritis, kreatif, dan pengambilan keputusan (Berns \& Erickson (200I) dalam Setiawan (20I3)). Jadi pembelajaran yang memberdayakan kemampuan berpikir kritis mahasiswa terkait erat dengan pemahaman konsep mahasiswa.

Rata-rata nilai kelas hasil analisis kritis artikel pada siklus I, II, dan III secara berurutan, yaitu 76, 87, dan 90. Peningkatan kemampuan berpikir kritis dari siklus I ke siklus II sebesar I5\% sedangkan peningkatan kemampuan berpikir kritis dari siklus II ke III sebesar $3,4 \%$. Tujuan berpikir kritis adalah mencapai pemahaman yang lebih mendalam pada diri mahasiswa. Keterampilan berpikir memiliki banyak manfaat, kemampuan berpikir kritis dapat membantu seseorang mengambil keputusan secara tepat berdasarkan usaha yang cermat, sistematis, logis, dan mempertimbangkan berbagai sudut pandang.

Kemampuan komunikasi mahasiswa dinilai berdasarkan kegiatan presentasi. Berdasarkan hasil paparan data dan temuan penelitian maka dapat diketahui bahwa rata-rata nilai kelas untuk kemampuan komunikasi pada siklus I, II, dan III secara berurutan, yaitu 52, 63, dan 63. Peningkatan kemampuan komunikasi dari siklus I ke siklus II sebesar 21\% sedangkan peningkatan kemampuan komunikasi mahasiswa dari siklus II ke siklus III sebesar $0 \%$.

Secara lengkap data hasil penelitian berupa perbandingan nilai kemampuan berpikir kritis dan komunikasi mahasiswa pada siklus I, II, dan III disajikan pada Tabel I berikut.

Tabel I. Data Perbandingan Peningkatan Kemampuan Berpikir Kritis dan Komunikasi Mahasiswa

\begin{tabular}{ccc}
\hline $\begin{array}{c}\text { Tindakan pada } \\
\text { Siklus ke- }\end{array}$ & $\begin{array}{c}\text { Kemampuan } \\
\text { Berpikir Kritis }\end{array}$ & $\begin{array}{c}\text { Kemampuan } \\
\text { Komunikasi }\end{array}$ \\
\hline I & 76 & 52 \\
II & 87 & 63 \\
III & 90 & 63 \\
\hline
\end{tabular}

\section{Simpulan}

Kesimpulan penelitian ini sebagai berikut.

I. Metode diskusi-presentasi dipadu dengan analisis kritis artikel melalui lesson study dapat meningkatkan pemahaman konsep mahasiswa sebesar $82 \%$, nilai tersebut termasuk dalam kriteria pemahaman konsep tinggi.

2. Metode diskusi-presentasi dipadu dengan analisis kritis artikel melalui lesson study dapat meningkatkan kemampuan berpikir kritis mahasiswa. Peningkatan kemampuan berpikir kritis dari siklus I ke siklus II sebesar I5\% sedangkan peningkatan kemampuan berpikir kritis dari siklus II ke III sebesar 3,4\%.

3. Metode diskusi-presentasi dipadu dengan analisis kritis artikel melalui lesson study secara umum dapat meningkatkan kemampuan komunikasi mahasiswa. Peningkatan kemampuan komunikasi dari siklus I ke siklus II sebesar 21\% sedangkan peningkatan 
kemampuan berkomunikasi mahasiswa dari siklus II ke siklus III sebesar 0\%.

4. Pelaksanaan pembelajaran Biologi Umum dengan metode diskusi-presentasi dan analisis kritis artikel yaitu mahasiswa mencari artikel kemudian menganalisisnya. Kegiatan awal pembelajaran yaitu mahasiswa presentasi materi kemudian diskusi kelas, setelah itu mahasiswa mempresentasikan hasil kajian analisis kritis artikelnya.

\section{Daftar Pustaka}

Anderson dan Krathwol. 200I. A Taxonomy for Learning, Teaching, and Assesing: Revition of Bloom's Taxonomy Educational Objectives. New York: Longman.

Aswandi. 2006. Guru sebagai Peneliti. (Online). (http://www.pontianakpost.com), diakses II Desember 2015.

Dewan Riset Nasional. 2013. Analisis Kritis. (Online). (www.drn.go.id/index.php /en/47-artikel-iptek/7analisis-kritis), diakses tanggal 19 Desember 2015.

Ennis, R. H. 20I I. The Nature of Critical Thinking: An Outline of Critical Thinking Disposititions and Abilities. (Online), (http://faculty.education. Illinois.edu/rhennis/documents/TheNatureofCriticalT hinking_5I7II_000.pdf), diakses II Desember 2015.

Filsaime, D. K. 2008. Menguak Rahasia Berpikir Kritis dan Kreatif. Jakarta: Prestasi Pustakarya.

Hassoubah, Z. I. 2004. Developing Creative and Critical Thinking skills (Cara Berpikir Kreatif dan Kritis). Bandung: Nuansa.

Kusumawati, S. N. 20I4. Pengaruh Pembelajaran Berbasis Otak melalui Learning Cycle terhadp Kemampuan Berpikir Kritis, Berpikir Kreatif, dan Hasil Belajar Biologi Siswa SMK Kota Malang. Tesis Tidak Diterbitkan. Malang: PPs UM.

Majid, A. 2013. Strategi Pembelajaran. Bandung: Remaja Rosdakarya.

Marzano, et al. 1988. Dimensions of Thinking: A Framework for Curiculum and Instruction. Alexandris Association for Supervision and Curriculum Development.

Moleong, L. 2006. Metodologi Penelitian Kualitatif. Bandung. PT Remaja Rosdakarya.

Mulyana, S. 2006. Pelatihan Lesson Study untuk Guru-guru Berprestasi Tingkat Nasional. Laporan Kegiatan Pelatihan Tahun 2006.

Purwanto, N. 2008. Prinsip-prinsip Evaluasi dan Teknik Evaluasi Pengajaran. Bandung: PT Remaja Rosda Karya.

Setiawan, D. C. 2013. Pengaruh Strategi Reciprocal Teaching Dipadu Pemberdayaan Berpikir Melalui Pertanyaan (PBMP) terhadap Kemampuan Metakognitif, Berpikir Kritis, dan Pemahaman Konsep Biologi Siswa SMAI AI Ma'arif Singosari Malang. Tesis Tidak Diterbitkan. Malang: PPs UM.

Somantri, N. 2005. Metode Presentasi dengan Ms Power Point untuk Mengembangkan Kemampuan Writing dan Speaking. Artikel. Pendidikan Network. http://re- searchengines.com/0305somantri2.html), diakses I5 Desember 2015.

Sukanti. 2008. Meningkatkan Kompetensi Guru melalui Pelaksanaan Penelitian Tindakan Kelas. Jurnal Pendidikan Akuntansi Indonesia, Vol. VI. No. I. Tahun 2008.

Syamsuri, I dan Ibrohim. 2007. Lesson Study (Studi Pembelajaran). Malang: UM Press.

Ulya, H. 201 I. Hubungan antara Kemampuan Berkomunikasi dengan Hasil Belajar Siswa melalui Pembelajaran Kooperatif Tipe Jigsaw. Skripsi Tidak Diterbitkan. Jakarta: UIN Syarif Hidayatullah Jakarta. 